\title{
Pawet Kasprzyk
}

ORCID 0000-0003-2454-9981

\section{Graduat Priusquam te formarem z Graduatu Jana Olbrachta w świetle cuthenticum fontium gregorianorum $^{1}$}

\begin{abstract}
Rozwój badań nad śpiewem gregoriańskim pozwala na coraz pełniejsze rozumienie i poznawanie repertuaru muzycznego, który Kościół w liturgii uznaje za pierwszy wśród równych ${ }^{2}$. Ruch jego odnowy znalazł kulminację w życiu o. Eugène’a Cardine’a, którego odkrycia stanowią fundament semiologii gregoriańskiej. Do jej kluczowych elementów należą: grupowanie neumatyczne, reperkusja dźwięków znajdujących się na tej samej wysokości oraz elastyczność czasu sylabicznego ${ }^{4}$. Jednym z kierunków objętych przez kontynuatorów gregoriańskiej myśli Cardine’a jest praca nad restytucją melodyczna kompozycji zawartych w Graduale Romanum ${ }^{5}$. Efektem
\end{abstract}

1 Artykuł stanowi kontynuację i uzupełnienie pracy dyplomowej Graduat „Priusquam te formarem" w świetle wybranych źródet napisanej przeze mnie w 2018 roku na zakończenie Studiów Podyplomowych z Monodii Liturgicznej na Wydziale Historii i Dziedzictwa Kulturowego UPJPII pod kierunkiem s. dr hab. Susi Ferfoglii, prof. UPJPII. W tym miejscu chciałbym też serdecznie podziękować dyrektorowi Archiwum i Biblioteki Krakowskiej Kapituły Katedralnej, ks. prof. dr. hab. Jackowi Urbanowi za udostępnienie kart rękopisu Graduału króla Jana Olbrachta, bez których napisanie niniejszej pracy nie byłoby możliwe.

2 Por. Sobór Watykański II, Konstytucja o liturgii świętej, 116, w: https://vademecumliturgiczne.pl/2017/06/26/konstytucja-o-liturgii-swietej-sacrosanctum-concilium/ (30.03.2020).

3 E. Cardine, Semiologia Gregoriana, Pontificio Instituto di Musica Sacra, Roma 1979. Książka przetłumaczona na język polski przez Macieja Kazińskiego i Michała Siciarka ukazała się nakładem Wydawnictwa Benedyktynów z Tyńca w 2000 roku jako Semiologia gregoriańska. W roku 2008 miało miejsce drugie wydanie.

4 Por. M. Sławecki, Gtówne aspekty śpiewu gregoriańskiego, w: M. Bornus-Szczyciński, A. Nowak, M. Sławecki, Monodia, Warszawa 2008.

5 Graduale Romanum, Sacrosanctae Romanae Ecclesiae de tempore et de sanctis, Roma 1908 [editio typica]. 
wieloletnich badań było wydanie dwóch tomów Graduale Novum ${ }^{6}(\mathrm{GN})$, zawierających odrestaurowane melodie ${ }^{7}$ oraz zapis notacji adiastematycznych pochodzących z dwóch rodzin - sanktgalleńskiej ${ }^{8}$ (GAL) i loreńskiej ${ }^{9}$ (LAN).

Dostęp do takiego ogromu wiedzy, jak również przeprowadzenie restytucji melodycznej kompozycji gregoriańskich daje impuls do badań późniejszych świadectw śpiewu liturgicznego Kościoła w kontekście authenticum fontium gregorianorum gregoriańskiego źródła repertuaru. Do dziś stanowi on podstawę muzycznej warstwy liturgii Kościoła rzymskokatolickiego.

Wpisując się w ten nurt, chciałbym przedstawić graduał Priusquam te formarem przeznaczony na święto Narodzin Jana Chrzciciela zapisany na kartach $112 \mathrm{v}$ i 113 jednego z najcenniejszych zabytków wawelskiego Archiwum Kapituły Katedralnej. Jest to spisany na początku XVI wieku rękopis o sygnaturze ms. 44 Graduał króla Jana Olbrachta $(\mathrm{Rkp} 44)^{10}$. Wykorzystana melodia restytuowana pochodzi z 2. tomu GN.

\section{Transkrypcja utworu}

Odczytanie melodii kompozycji zapisanej w Rkp. 44 nie przysparza trudności. Jasny i czytelny sposób zapisu pozwala na bezproblemowe rozpoznanie przebiegu interwałowego. Wątpliwości dotyczą natomiast grupowania dźwięków. Istnieją fragmenty, w których nie jest łatwo określić intencję kopisty na podstawie analizy wyłącznie jednej kompozycji. Za przykład niech posłuży melizmat na słowie te w zakończeniu responsu:

6 Graduale Novum, t. 1: De dominincis et festis, Regensburg-Vaticano 2011; Graduale Novum, t. 2: De feriis et sanctis, Regensburg-Vaticano 2018.

7 Dotychczas komentarz naukowy został napisany i wydany tylko w języku niemieckim: J. B. Göschl, Graduale Novum Kommentar, Regensburg 2018.

8 W przypadku omawianego utworu jest to rękopis: St. Gallen, Stiftsbibliothek, ms. 359: Cantatorium, f. 121.

9 Ville de Laon, Bibliothèque Municipale, ms 239: Graduel de Laon, f. 132.

10 Istnieje kilka prac opisujących omawiany zabytek, m.in.: M. Popowska, Graduat maryjny ms. 42 Jana Olbrachta w tradycji krakowskiej - studium źródtoznawcze, Częstochowa 2003; B. Miodońska, Rex Regnum $i$ Rex Poloniae w dekoracji malarskiej Graduatu Jana Olbrachta i Pontyfikatu E. Ciotka. Z zagadnień ikonografii wtadzy królewskiej w sztuce polskiej wieku XVI, Kraków 1979; M. Klich, Przebieg melodyczny offertorium „Ave Maria” zachowanego w rękopisie nr 44 Archiwum Krakowskiej Kapituty w świetle wzorców, praca dyplomowa napisana na Wydziale Historii i Dziedzictwa Kulturowego, Podyplomowe Studia z Monodii Liturgicznej, Kraków 2019. 


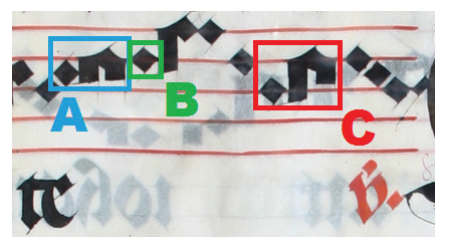

Ryc. 1. Melizmat nad słowem te, które kończy respons graduatu (fol. 113/2)

Wskazany fragment dopuszcza kilka potencjalnych interpretacji zapisu. Zaznaczona literą A grupa trzech dźwięków w formie izolowanej oznacza torculus. Przyjmując taką wersję, pierwszy dźwięk całego melizmatu zostaje oddzielony, sugerując artykulację początkową (por. przykład pierwszy na Ryc. 2). Oddzielenie pierwszego dźwięku byłoby czymś nietypowym w świetle analizy innych fragmentów w rękopisie $^{11}$. Wydaje się, że pierwszy dźwięk melizmatu tworzy jedną grupę z omawianymi trzema - które razem składają się na neumę scandicus flexus.

Problem grupowania dotyczy też kolejnego (tj. piątego) dźwięku rozważanego melizmatu (zob. Ryc. 1/B). Może on tworzyć jedną grupę z dźwiękami poprzedzającymi (łącząc się w porrectus praebipunctis, a kolejny staje się izolowaną virgą) lub z dźwiękiem znajdującym się po nim, stając się inicjalnym elementem pesa (por. przykład drugi i trzeci na Ryc. 2). Pierwsze rozwiązanie wydaje się o tyle nieprawdopodobne, że w całym omawianym utworze izolowana virga nie pojawia się ani razu (zawsze stanowi ona element większej grupy).

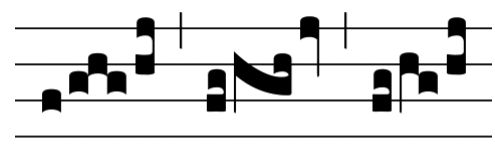

te. te. te.

Ryc. 2. Rożne możliwości interpretacji grupowania początkowych sześciu dźwięków melizmatu

Spośród zaznaczonych fragmentów melizmatu kończącego respons graduału (Ryc. 1) najbardziej jednoznaczny wydaje się być ten opatrzony literą C. Ponownie, wskazane trzy dźwięki (w izolacji) oznaczają torculus. Musimy jednak odwołać

11 Istnieją miejsca, gdzie artykulacja początkowa, zgodnie ze źródłami adiastematycznymi, w gregoriańskim pierwowzorze utworu rzeczywiście występuje. Autor Rkp. 44 jednak pomija ją i łączy pierwszy dźwięk z następującym po nim, np. w słowie dixit w drugiej części wersetu. 
się do dwóch poprzednich dźwięków, których autor rękopisu nie zanotował jako clivis (który w analizowanym rękopisie posiada własny znak $\mathbf{T})$, a jako virgę oraz punctum. Zatem i kolejne punctum (tj. pierwszy dźwięk grupy C) musi tworzyć z nimi trzydźwiękowy climacus i nie może być częścią torculusa.

Finalnie transkrypcja całego fragmentu wygląda następująco:

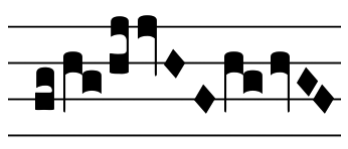

te.

Ryc. 3. Transkrypcja melizmatu kończącego respons kompozycji

Powyższe przykłady obrazują trudności, które dotyczyły transkrypcji także innych miejsc analizowanego utworu. Prowadzi to do bardzo ważnej hipotezy: dla autora rękopisu grupowanie dźwięków nie było istotne i nie zmieniało interpretacji kompozycji. W charakterystyczny dla siebie sposób łączy on kolejne dźwięki, kiedy tylko pozwala mu na to wykorzystywana notacja. Innymi słowy, zapis ten ma na celu przekazać jedynie przebieg interwałowy kompozycji, nie niosąc informacji rytmicznej. Potwierdzenie tego twierdzenia wymaga przeprowadzenia nad rękopisem badań paleograficznych, które uwzględniałyby podział na znaki stosowane $w$ izolacji oraz $w$ kompozycji.

\section{Graduat Priusquam w świetle gregoriańskiego pierwowzoru}

\section{Wspólne źródto}

Kompozycja zachowana w Rkp. 44 już na pierwszy rzut oka pozwala dostrzec bardzo duże podobieństwo do odrestaurowanego pierwowzoru. Szczegółowa analiza wykazuje obecność licznych różnic. Nie zmieniają one jednak gregoriańskiej tożsamości utworu, nie zostawiając wątpliwości odnośnie do jego pochodzenia. Graduał podzielony jest na respons oraz werset. W obu źródłach posiada ten sam tekst pochodzący z Księgi Jeremiasza 1, 5. 9:

$\grave{R}$ Priusquam te formarem in utero, novi te: et antequam exires de ventre, sanctificavi te.

V Misit Dominus manum suam, et tetigit os meum, et dixit mihi ${ }^{12}$.

12 „Zanim ukształtowałem cię w łonie matki, znałem cię, nim przyszedłeś na świat, poświęciłem cię". (...) Wyciągnąwszy rękę, dotknął Pan moich ust i rzekł mi” (Pismo Święte Starego i Nowego 
Pod względem estetyczno-modalnym kompozycje są tożsame. Stopień FA, na którym mocno osadzony jest początek responsu, jest także stopniem dominującym strukturalnie w całej pierwszej jego części (aż do słów novi te). Melodia drugiej części responsu modalnie opiera się na dwóch wyższych stopniach: LA i DO, choć finalnie, w rozbudowanym melizmacie, opada na FA, które jest także finalis całej kompozycji ${ }^{13}$. Werset graduału posiada strukturę bardzo rozbudowanego tonu psalmowego. Jest to charakterystyczne dla tej formy liturgiczno-muzycznej. Kompozytor pomija w tym wypadku intonatio. Pierwszą część rozpoczyna od razu na stopniu DO, pełniącym funkcję tenoru psalmowego, kwintę ponad finalis. Również mediatio (na słowie suam) kończy się na tym samym stopniu. Część druga jest opisana melodycznie na trzech stopniach: DO, LA i FA, tworząc rozbudowane terminatio. Przedstawiona charakterystyka pozwala jednoznacznie zaklasyfikować kompozycję do V modusu wg teorii octoechos - tetrardusa autentycznego ${ }^{14}$.

\section{Różnice}

Różnice między kompozycjami w obu wersjach możemy podzielić na dwie grupy ${ }^{15}$.

Pierwszą z nich stanowią zmiany melodyczne. Dotyczą one zanikających dźwięków likwescencji pomniejszających (np. priusquam, ante[quam]) i zmian interwałowych (np. novi te - pes subbipuctis, wg GN: LA-SIb, natomiast wg Rkp. 44: LA-DO. Przykładem, na który chciałbym zwrócić szczególną uwagę jest pes LA-RE na słowie mihi, w ostatniej części wersetu. Interwał zanotowany przez autora wawelskiego rękopisu różni się od restytucji melodycznej z GN (DO-RE). Wersja ta ma jednak ewidentne poparcie w LAN (por. Ryc. 4). Metzeński kopista zapisał bardzo długi pes (wyraźnie różnicując go w stosunku do użytego chwilę wcześniej na początku słowa dixit), który zaczyna się na tej samej wysokości, co poprzedzający go finalny dźwięk słowa dixit ${ }^{16}$. Analogiczna sytuacja dotyczy nadmiarowego, względem GN, dźwięku FA na słowie Dominus w wersecie. Również w tym miejscu

Testamentu $w$ przektadzie z języków oryginalnych, oprac. zespół biblistów polskich z inicjatywy benedyktynów tynieckich (Biblia Tysiąclecia), Poznań-Warszawa 1990.

13 Zgodnie z formą responsorium po wykonaniu wersetu powtarza się respons.

14 Por. D. Saulnier, The Gregorian Modes, trans. E. Schaefer, Solesmes 2002, s. 79-86.

15 Pomijam w tym miejscu opisane wcześniej różnice w grupowaniu dźwięków wynikające z samej charakterystyki paleograficznej rękopisu.

16 Mimo iż jest to notacja adiastematyczna, wykazuje ona pewne cechy diastematyzujące. Kopista, choć nie notuje dokładnych odległości, w świadomy sposób przestrzennie rozmieszcza znaki, dając bardzo jasne wskazówki odnośnie do kierunku melodii i interwałów między sąsiadującymi dźwiękami. 
LAN przekazuje wersję melodyczną zawierającą o jeden dźwięk więcej. Sugeruje to, że równolegle funkcjonowały dwa warianty. Może to stanowić interesujący trop w badaniu nie tylko samego rękopisu, lecz także monodii liturgicznej obecnej na terenach polskich w XVI wieku.

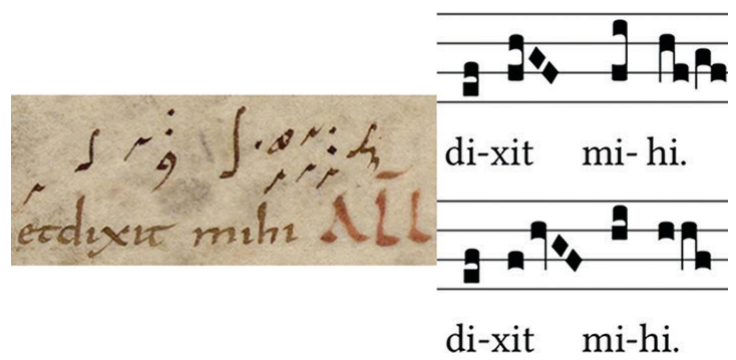

Ryc. 4. Po lewej - rękopis LAN. Po prawej dwie wersje melodyczne, pochodzące z Rkp. 44 (górna) oraz z GiN (dolna)

Drugą grupę różnic stanowią zmiany estetyczne. W bardzo wielu miejscach sąsiadujące dźwięki na tej samej wysokości zostały sprowadzone do jednej nuty. Co ciekawe, ma to miejsce nie tylko w przypadku reperkusji na tej samej sylabie (np. antequam), lecz także w przypadku dwóch sylab tekstu. W melodii z GN pierwszy dźwięk na słowie ventre (oddzielony jako artykulacja początkowa od grupy kolejnych) nie występuje w wersji melodycznej z Rkp. 44. Był on jednak na tej samej wysokości, co poprzedzający go dźwięk na sylabie de. Przykład przedstawiony jest na Ryc. 5.

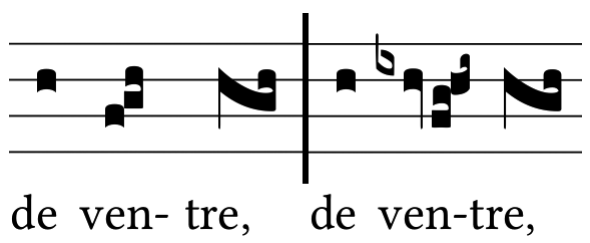

Ryc. 5. Różnice melodyczne między Rkp. 44 (po lewej) i GN (po prawej)

Niezwykle interesujący jest także wpływ prezentowanego zjawiska na figury melodyczne kończące respons i werset. Na Ryc. 6 zaznaczone zostały fragmenty odpowiadające sobie pod względem strukturalnym (rękopis zachowuje te same dźwięki strukturalne - każdy z nich traktuje jednak na równi). Miejsca te zostały znacząco uproszczone w stosunku do oryginału pod względem melodycznym, a w konsekwencji także i rytmicznym. Z punktu widzenia semiologicznego 
melizmat został pozbawiony wirtuozerii, którą prezentuje kompozycja przechowana w najstarszych rękopisach.

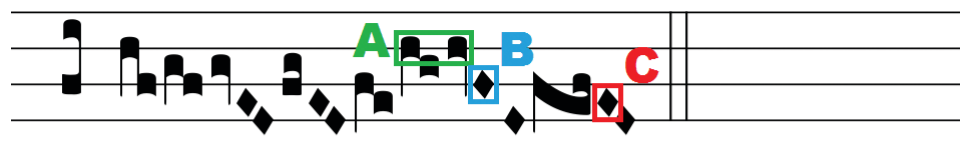

mi- hi.

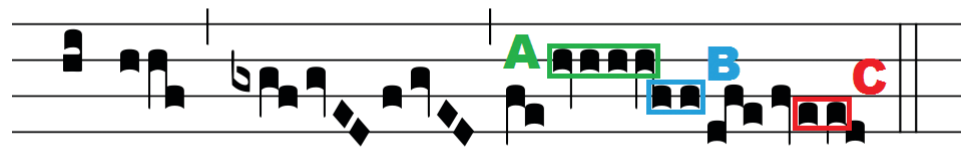

mi-hi.

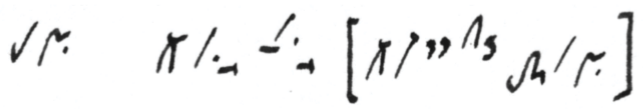

Ryc. 6. Efekt uproszczenia rytmiczno-melodycznego melizmatu kończącego werset w Rkp. 44 (u góry) względem GN (na środku). Rytm zapisany w rękopisie GAL (na dole) jest niemożliwy do realizacji przez znieksztatcenie melodii

\section{Zakończenie}

Wersja graduału Priusquam te formarem przechowywana w Rkp. 44 oraz restytuowana wersja melodyczna z GN wykazują szereg podobieństw. Szczegółowa analiza ujawnia jednak wiele istotnych różnic. Niewątpliwie jest to świadectwo przemian i wpływów, którym ulegał liturgiczno-muzyczny repertuar Kościoła. Pierwotny charakter omawianego graduału został całkowicie zatracony. Wpłynął na to czas, który dzielił powstanie kompozycji gregoriańskiej i spisanie krakowskiego rękopisu. Notacja muzyczna ukierunkowana na przekazanie melodii pozbawiona jest wskazówek rytmicznych. Wynikające z tego zatracenie gregoriańskiego charakteru utworu przejawia się przede wszystkim w uproszczeniach rytmicznych i estetycznych (brak reperkusji, wszystkie stopnie skali traktowane tak samo). Pomimo to, na gruncie polskim Graduał Jana Olbrachta pozostaje bezcennym zabytkiem muzycznym. Świadczy on o tym, że śpiew, będący integralną częścią liturgii, stanowił istotny element historii naszego kraju. Także i dziś należy dołożyć starań, by nie został zapomniany. 

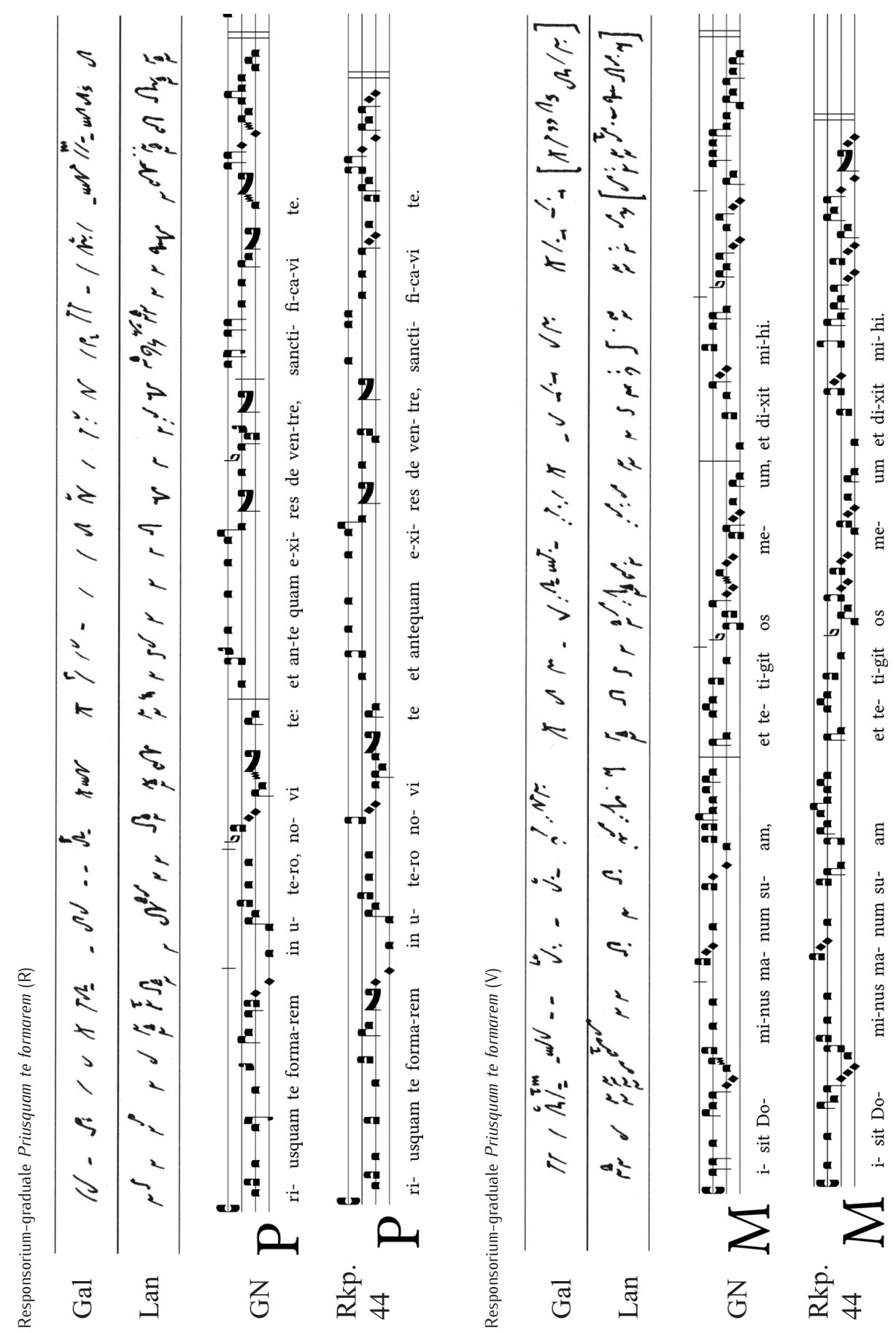


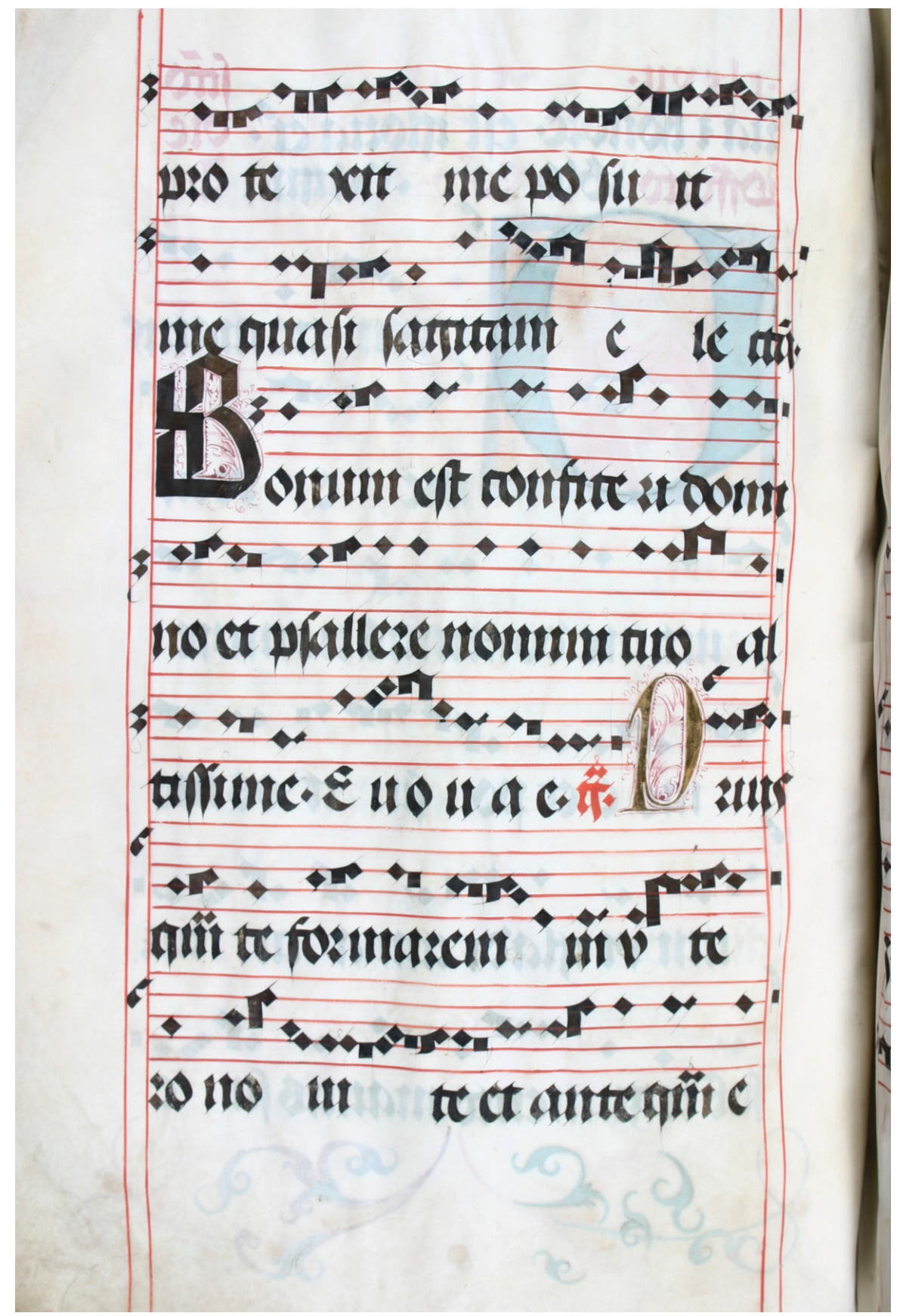




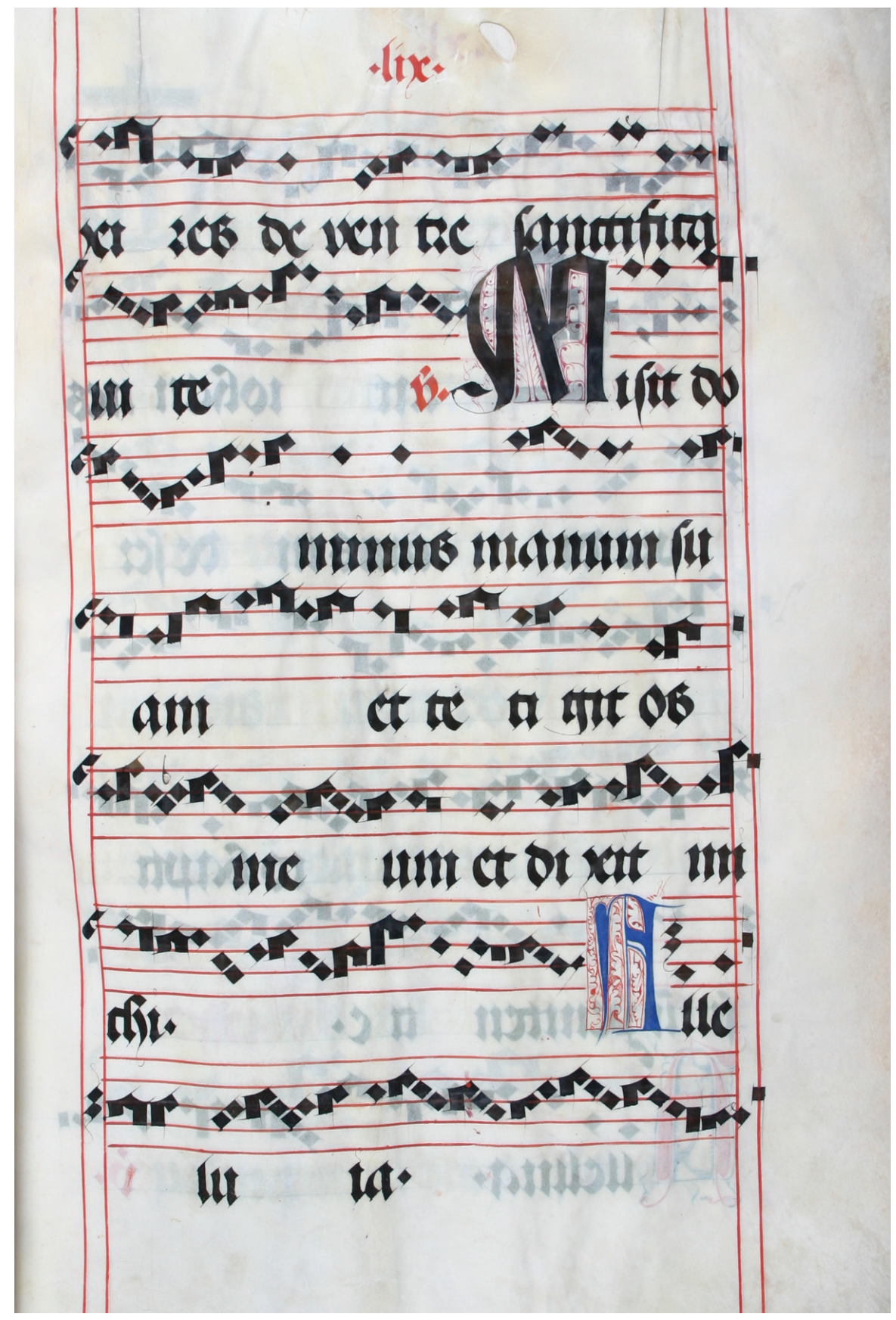

Ryc. 8. Karta 113 pochodząca z Rkp. 44 


\begin{abstract}
Abstrakt
Współczesny stan wiedzy na temat śpiewu gregoriańskiego zawdzięczamy przede wszystkim badaniom prowadzonym nad najstarszymi rękopisami. Owocem tych badań jest m.in. możliwość analizowania przekształceń, którym ulegał autentyczny repertuar gregoriański na przestrzeni wieków. Jednym z najcenniejszych zabytków liturgiczno-muzycznych na gruncie polskim jest datowany na początek XVI wieku Graduał króla Jana Olbrachta, przechowywany w Archiwum Kapituły Katedralnej na Wawelu. Analiza graduału Priusquam te formarem, przeznaczonego na święto Narodzin Jana Chrzciciela, pokazuje, jak pochodząca z VIII wieku melodia została uproszczona na przestrzeni lat, tracąc swój gregoriański charakter.
\end{abstract}

Stowa kluczowe: semiologia gregoriańska; chorał gregoriański; interpretacja gregoriańska; graduał Jana Olbrachta; restytucja melodyczna; analiza melodyczna

\title{
Abstract \\ Graduale Priusquam te formarem in the context of Authenticum Fontium Giregorianorum
}

Contemporary knowledge on Gregorian Chant is mainly attributed to research conducted on oldest manuscripts. As a result we gained abilities to analyze the transformations which a Gregorian repertoire underwent on the course of ages. One of the most precious liturgical and musical monuments preserved in Poland is a 16th-century Graduale of King Jan Olbracht, stored in Archiwum Kapituły Katedralnej on Wawel, Kraków. Analysis of a graduale Priusquam te formarem for the feast of Birth of John the Baptist shows how an 8th-century melody has been simplified, losing its Gregorian characteristics.

Keywords: Gregorian semiology; gregorian chant; gregorian interpretation; Jan Olbracht graduale; melodic restitution; melodic analisys 


\section{Bibliografia}

\section{Źródta}

Graduale Novum, t. 1: De dominincis et festis, Regensburg-Vaticano 2011.

Graduale Novum, t. 2: De feriis et sanctis, Regensburg-Vaticano 2018.

Graduale Romanum, Sacrosanctae Romanae Ecclesiae de tempore et de sanctis, Roma 1908.

Graduat maryjny ms. 44 Jana Olbrachta, Archiwum Krakowskiej Kapituły Katedralnej, faksymile.

Pismo Święte Starego i Nowego Testamentu w przektadzie z języków oryginalnych, oprac. zespół biblistów polskich z inicjatywy benedyktynów tynieckich (Biblia Tysiąclecia), Poznań-Warszawa 1990.

Sobór Watykański II, Konstytucja o liturgii świętej w: https://vademecumliturgiczne. pl/2017/06/26/konstytucja-o-liturgii-swietej-sacrosanctum-concilium/ (30.03.2020).

St. Gallen, Stiftsbibliothek, Cod. Sang. 359: Cantatorium, faksymile.

Ville de Laon, Bibliothèque Municipale, Ms 239: Graduel de Laon, faksymile.

\section{Opracowania}

Cardine E., Semiologia gregoriańska, Kraków 2008.

Cardine E., Semiologia Gregoriana, Roma 1979.

Göschl J. B., Graduale Novum Kommentar, Regensburg 2018.

Kasprzyk P., Graduat „Priusquam te formarem” w świetle wybranych źródet. Praca dyplomowa napisana na Wydziale Historii i Dziedzictwa Kulturowego, Podyplomowe Studia z Monodii Liturgicznej, Kraków 2018.

Klich M., Przebieg melodyczny offertorium „Ave Maria” zachowanego w rękopisie nr 44 Archiwum Krakowskiej Kapituty w świetle wzorców. Praca dyplomowa napisana na Wydziale Historii i Dziedzictwa Kulturowego, Podyplomowe Studia z Monodii Liturgicznej, Kraków 2019.

Miodońska B., Rex Regnum i Rex Poloniae w dekoracji malarskiej Graduatu Jana Olbrachta i Pontyfikatu E. Ciotka. Z zagadnień ikonografii wtadzy królewskiej w sztuce polskiej wieku XVI, Kraków 1979.

Popowska M., Graduat maryjny ms. 42 Jana Olbrachta w tradycji krakowskiej - studium źródtoznawcze, Częstochowa 2003.

Saulnier D., The Gregorian Modes, trans. E. Schaefer, Solesmes 2002.

Sławecki M., Główne aspekty śpiewu gregoriańskiego w: M. Bornus-Szczyciński, A. Nowak, M. Sławecki, Monodia, Warszawa 2008. 